\title{
Shakespeare's Progress from the Narrative Poems to the Sonnets
}

L'avancée de Shakespeare des poèmes narratifs aux Sonnets.

\section{Robert Ellrodt}

\section{(2) OpenEdition \\ 1 Journals}

\section{Electronic version}

URL: http://journals.openedition.org/shakespeare/1041

DOI: $10.4000 /$ shakespeare.1041

ISSN: 2271-6424

\section{Publisher}

Société Française Shakespeare

\section{Printed version}

Date of publication: 1 November 2007

Number of pages: 97-117

ISBN: 2-9521475-3-1

\section{Electronic reference}

Robert Ellrodt, "Shakespeare's Progress from the Narrative Poems to the Sonnets », Actes des congrès de la Société française Shakespeare [Online], 24 | 2007, Online since 30 March 2010, connection on 10 December 2020. URL : http://journals.openedition.org/shakespeare/1041 ; DOI : https://doi.org/ 10.4000/shakespeare.1041

This text was automatically generated on 10 December 2020 .

(c) SFS 


\title{
Shakespeare's Progress from the Narrative Poems to the Sonnets
}

\author{
L'avancée de Shakespeare des poèmes narratifs aux Sonnets.
}

\section{Robert Ellrodt}

1 In a chapter on the 1986 edition of the Cambridge Companion to Shakespeare Studies, I devoted ten pages to the Sonnets and two pages only to the narrative poems. In my bilingual edition of "Shakespeare's Poems" I have made amends since the twenty-four pages of commentary on Venus and Adonis and The Rape of Lucrece exceed the twenty pages granted to the Sonnets. ${ }^{1}$ The keen interest in the epyllia displayed in recent criticism dictated the change. However, like Frank Kermode in Shakespeare's Language, ${ }^{2}$ I feel free "to value one text over another".

2 The narrative artistry of Shakespeare is obvious in the vivacity of his openings in medias res and his dramatic craft is displayed in the assault of Venus on the reluctant boy, or Tarquin's stealthy progress through the corridors of Lucrece's house. ${ }^{3}$ The scuffling between the Goddess and Adonis, their successive postures, are an entertaining, yet rather facile stage action. ${ }^{4}$ The ratiocination of Tarquin cannot move us like the more spontaneous ruminations of Macbeth. After the rape, the flow of narrative is lengthily held up for the sake of oratorical display (764-1029) or "skilful painting" (1366-1568). The story of Troy has but the faintest link with the rape of Lucrece: the dissembling of Tarquin proved as treacherous and fatal as Sinon's was for Troy. The complaint of the heroine is wearisome like the "heavy anthem" of Venus (839), which the poet had more wisely alluded to, not recorded. Rhetorical prolixity was expected in Elizabethan poetry, but Marlowe did not overindulge it in Hero and Leander.

3 A sonnet sequence did not invite narrative skill in the telling of a story, but the best ones, Petrarch's, Spenser's and Sidney's, spoke of a love relationship which had a beginning and came to an end after several episodes. ${ }^{5}$ Shakespeare's Sonnets may be considered as a discontinuous set of poems. Yet three actors are purposely contrasted in sonnet 144 as if they were characters in a Morality play. In sonnets 34 to 36 and 40 to 42 a triangular love affair creates a dramatic interest revived in the sonnets to a dark mistress. Intriguing 
allusions to specific, though unknown, circumstances are scattered throughout. ${ }^{6}$ The three year period mentioned in sonnet $104^{7}$ may be symbolic, but together with the poem addressing the lovely boy who has "by waning grown" (126), it implies at least an intention of continuity in the composition of the sonnets.

It has been argued we cannot be certain all the sonnets in the first group were written for a single young man. ${ }^{8}$ One may admit that Petrarch's Laura was partly a symbol, that some of Spenser's Amoretti may not have been originally written for Elizabeth Boyle, nor some of Sidney's for Penelope Rich, but the sequences were obviously intended to be about one beloved, not about several women. Shakespeare's Sonnets, as published, never invite the reader to think of several young men. ${ }^{9}$ The "friend" always appears to be a social superior and always exhibits contrasting characteristics of loveliness and corruption, apparent constancy and fickleness, eliciting throughout the same ambivalent responses. ${ }^{10} \mathrm{~A}$ "deconstruction" of the sequence may prove as arbitrary as any of the re-orderings earlier attempted, and some of the poems, obviously interrelated, ${ }^{11}$ might lose part of their interest.

5 I therefore still choose to read the Sonnets as the disorderly record of a perplexing story (real or imagined) about a love relationship between a poet and a young man, and a sex affair involving the poet, his mistress and this young man. The relation with the "lovely boy" apparently comes to an end in the twelve-line farewell poem (126). The sex affair seems to have no denouement. The usual recantation of earthly love (146) is not placed last, and the next sonnet (147) suggests a failure to quench "a fever, longing still [my italics]". The mythological sonnets may hint at venereal infection ${ }^{12}$, or simply indicate that the "sad distempered" lover did "find no cure" for his still burning desire.

6 In the first nineteen sonnets there is evidence of careful planning in the progression from the theme of immortality through generation ${ }^{13}$ to immortality through poetic praise, a praise which is gradually discovered to be an expression of the poet's love for the young man. ${ }^{14}$ Sonnet 20, on "the master-mistress of [his] passion," defines the nature of this love, which may or may not include sex..$^{15}$ Anyhow, to distinguish "love" from "love's use" opens up, beyond sexual pleasure, a wide range of emotional symptoms, preoccupations and thoughts: ageing and its effects $(2,3,11,19,22,63,73,77)$, anxiety at the prospect of mortality - the young man's ${ }^{16}(12-18,64-65)$ or the poet's $(32,71-74)-$, moods and dreams created by absence $(27,28,39,43-45,50-52,61,97-99,113)$, competition for love and patronage with a rival poet (80-86), pain and forgiveness at the "trespass" or corruption of the beloved (33-36, 40-42, 57, 58, 69, 70, 93-96), grief at estrangement and separation (48-49, 87-92), self-depreciation and apology $(57,62,71-73,80-84,103)$ self-accusation or self-justification (109-112, 117-121), delight and confidence in the renewed force of love $(56,102,123-125) .{ }^{17}$ When the speaker, after "wretched errors," finds it true "That better is by evil still made better" (119), one is reminded of the "soul of goodness in things evil" discerned by King Henry (Henry V, IV.i.4).

7 Throughout the sequence there is a constant progress in the revelation of the complexity of the human psyche contrasting with the simple and static delineation of character in the narrative poems. The sonnets bring evidence of a vacillation of moods and judgment in the poet as in some heroes of the plays, notably Hamlet. The various ways in which the poet reacts to the triangular relationship are well illustrated by his different attitudes: a willing, yet disillusioned compliance with his friend, a bitter sensual enslavement to his mistress and his own desire. 
Desire had been the main theme of the narrative poems. In Venus and Adonis it is painfully experienced by a Goddess, who, like Cleopatra, is "no more but a woman." ${ }^{18}$ Her "quick desire" (547) is a woman's desire to arouse desire in a young man and to have all the sweets of her body tasted and rifled by him, which implies a vicarious enjoyment of those sweets: hence the elaborate and highly suggestive description of all the parts of her body (133-44, 229-40). The aesthetic appeal is less prominent than the expectation of sensual delight, and in her praise of the boy's beauty, the Goddess is particularly insistent on the attraction of the more material senses, touch, taste and smell (438-50; cf. 537-58). ${ }^{19}$ The animal nature of her passion is evidenced through the images of the eagle and the vulture (55-66, 547-58). At the close her desire is identified with the boar's assault and the castration instinct. ${ }^{20}$ Yet, as genetrix, Venus also embodies motherhood, but her identification with the doe "hasting to feed her fawn" (875-6), shows her "driven by pure animal instinct" as Muriel Bradbrook noted. ${ }^{21}$ Sex in its fresh vigour and its natural fulfilment is best represented by the mating of the stallion and the genet. Adonis justifies his rejection of sensual pleasure by a contrast between lust and true love, but irony creeps in when he confesses "the text is old, the orator too green" (806). A Platonic reading of the poem is groundless; a Lacanian reading superfluous. ${ }^{22}$

In The Rape of Lucrece "desire" is also the "pilot" (279) and its physical origin is emphasized in the opening lines $(4,7,9,47)$. It is again excited by beauty (490), but beauty seen as a "prize". René Girard made envy the motivating force, ${ }^{23}$ but Tarquin seems chiefly eager to maintain his social superiority. His pride of rank and delight in domination are expressed through rape as a form of military conquest and possession (407-13, 481-2, 488). His "will" (487) is desire, as in the "Will" sonnets, but chiefly as an exercise of will power.

In the sonnets to the dark mistress desire is again dominant (147). Its consummation is unashamedly evoked in sonnets 135, 136 and 151 (6-14). Love is rightly called "lust" in its obsession with the sexual act in "the forfended place" (Lear, v.i.11) for adultery is suggested in sonnet 142 . This love is divested of glamour since all aesthetic attraction is said to be absent. ${ }^{24}$ The dark mistress offers no "sensual feast" (141). The poet's desire is a "sickly appetite" (147), unrelated to a desire of beauty (137.3-4), and excited only by the pleasure reaped in sexual intercourse. ${ }^{25}$ Yet lust is attended by shame and a consciousness of self-deceit, which introduces more psychological complexity than in the narrative poems. Self-abused love, swayed by self-conscious desire, ends in self-disgust. These sonnets, if written before 1600 , introduce a new strain which will taint the noble mind of Hamlet, permeate the worlds of Troilus and Cressida and Measure for Measure, drive Othello to murder, and persist in the ravings of Lear, the diatribes of Timon. This sex nausea, first displayed by the satirists for obvious reasons, may have been consonant with real and personal anxieties in the plays of Shakespeare. ${ }^{26}$

11 Throughout the sonnets to the young man physical desire may be present, but it is muted. ${ }^{27}$ The dominant and essential emotion is love. Paul Edmonson and Stanley Wells rightly speak of the "infinite possibilities of desire both spiritual and physical" in the Sonnets. ${ }^{28}$ I choose the notion of "love" as more embracing than "spiritual desire". ${ }^{29}$ The word "desire" clearly applies to the poet's sexual desire in three sonnets to the mistress (141, $147,154)$, but in the first group it only expresses a longing for the perpetuation of "fairest creatures" (1.1) or for the presence of the young man $(45.3 ; 51.10)$. This desire is said to be made "of perfect'st love," but the nature of this love is not particularized. It may, or may not be sexual, and the insistence on its perfection may imply at least that, if it has to do 
with sex, it seeks to transcend it. ${ }^{30}$ Characteristically, when the poet speaks of the friend's intimacy with his mistress, he is not obsessed, as Othello and Leontes will be, by images of physical contact between the offending lovers. Sex becomes prominent only when he addresses the dark mistress, but attention is then focused on her promiscuousness, not on her love-making with the friend. Because his concern is mainly to preserve the sentimental bond with the young man, the poet can sincerely exclaim:

Take all my loves, my love, yea, take them all:

What hast thou more than that thou hadst before? (Sonnet 40)

My distinction between desire and love may be challenged, but it is based on aesthetic, not ethical reasons. Bruce Smith claims that genital desire is the "root of all the emotions associated with love." ${ }^{31}$ Long before him Miguel de Unamuno, the Spanish Kierkegaard, had acknowledged that "sexual love is the generating type of all other love," 32 but he insisted on its transmutation. I have earlier stressed the difference between Shakespeare's expression of homoerotic attractiveness and the luscious descriptions of Barnfield and Marlowe. ${ }^{33}$ The allusions to same sex intercourse some critics read in - or into - the sonnets to the young man are covert and cryptic, whereas copulation is open and blatant in the sonnets to the mistress: the impact on the reader's imagination is bound to be different. The fair youth is not presented as a prey for sensual desire, but as an object of aesthetic rapture: ${ }^{34}$ he sums all the loveliness of Nature, "the spring and foison of the year" (53). Gregory Wood assumes that the poet, when he praises the beauty "Of hand, of foot, of lip, of eye, or brow" in Sonnet 106 is "offering an erotic and seductive description of the body of his male lover to the reader." ${ }^{35}$ But the body here is, indeed, "left unseen save to the eye of mind," as in the tapestry on which Lucrece saw "A hand, a foot, a face, a leg, a head," which "stood for the whole to be imagined" (1426-28). The effect is different from the truly "erotic and seductive" descriptions in Venus and Adonis. Quite different too, from Marlowe's enraptured evocation of Leander's neck, breast and belly, or Barnfield's lingering attention to "naked limbs," "love-enticing soft limbs." 36

In Shakespeare's Sonnets the young man's attractiveness does invite "feasting on [the] sight" (75) of his physical beauty in accordance with the Platonic assumption that love is a desire of beauty, but the contemplation creates a kind of ecstasy which has little in common with mere carnal passion. The poet does not love the young man as he loves the dark mistress whose "face hath not the power to make love groan" (131). Furthermore, when celebrating the beloved and his beauty, he seems to be essentially celebrating his own love and love itself. In the great sonnet on "the marriage of true minds" (116), there is an obvious contradiction between the exaltation of perfect constancy and the admission that this constancy may not be found in one of the partners. The contradiction vanishes once it is clear that this love does not aim at possession: it is described as "the marriage of true minds," which calls to mind Jonathan Bate's apposite remark: "We do not need to know what happens in the bed, because what the sonnets are interested in is how love happens in the head." ${ }^{37}$ Yet no Platonic sublimation is attempted as in Michelangelo's poems ${ }^{38}$ The poet's deepest wish in sonnet 65 was "That in black ink my love may still shine bright": "my love" here, as in other sonnets, is at once "the young man I love" and "my own love," the poet's love and its poetic expression. This is the love which can be "built anew" after being "ruined" (119), for this "dear love" is not "the child of state," subject to time's love or hate, but is "builded far from accident" (124). The poet may not really care for the immortality of the unnamed beloved, nor even for his own immortality since he never shows the pride of a Ronsard: he seeks to convince himself of 
the immortality of love, a love that creates its own assurance of unassailable constancy. Not without ambiguity, I admit. Cleopatra's final attitude will later illustrate the same kind of precarious balance between sheer make-believe and a sense of transcendent glory, a claim to "immortal longings". What might be an illusion proves truth in the poem as in the play, not through Shakespeare's huge command of rhetoric, as Bernard Shaw disparagingly pretended, but through a poetic intensity fusing an intuition of essence with time's "millioned accidents" (115).

From the consideration of the nature of love in the Sonnets I therefore pass to an examination of its expression. Frank Kermode has traced the evolution of Shakespeare's language in the plays, but left the poems out of his field of enquiry. Yet a fairly similar progress can be traced from Venus and Adonis to the Sonnets.

The Elizabethan rites of mourning called for a lavish display of rhetoric. Shakespeare complied with the conventions in the narrative poems as in his earliest history plays. At the beginning of his career he probably thought it indispensable to achieve a reputation. But was the author of Venus and Adonis fully persuaded of its value? When Venus "begins a wailing note" (835) her song is declared "tedious" (841), which is said by editors to mean "long," but both in the OED, and in Shakespeare's works, when "tedious" means long, it always means both "long and wearisome." ${ }^{39}$ Besides, we are told that "Such copious stories [...] end without audience" (841-46). The condemnation of "painted rhetoric" in Love's Labour's Lost (v.ii.413) has been compared with the rejection of "painted beauty" in sonnet 21 and false art in sonnet $82 .{ }^{40}$ Shakespeare may have felt earlier than in 1599 that he would have to move "in the direction of a kind of reticence," as Kermode suggests. ${ }^{41}$

The form of the sonnet invited condensation, not copia. ${ }^{42}$ Yet it need not have excluded the "systematic simile production" denounced by Kermode in the early plays ${ }^{43}$ nor the stereotyped rhetorical figures characterized by repetition, or symmetry and balance, which recur insistently in the narrative poems. In the Sonnets, as George T. Wright observed, "we hardly ever find the same phrasing patterns in successive lines." ${ }^{44}$ This change, I suggested long ago, was not only an individual choice. ${ }^{45}$ It denoted a new taste, that of the Donne generation, and I have illustrated it by a close comparison of the Directions for Speech and Style of John Hoskyns, composed about 1599, ${ }^{46}$ with earlier treatises, Puttenham's Arte of English Poesie and Abraham Fraunce's Arcadian Rhetoricke. "Figures of thought" were given preference over "figures of sound". Repetitions of words or sounds were discountenanced, unless they served the meaning. What we very seldom find in the Sonnets is the kind of anaphoric monotony heard in these lines from the Rape of Lucrece (one instance among twenty): ${ }^{47}$

Let him have time to tear his curled hair,

Let him have time against himself to rave,

Let him have time of time's help to despair,

Let him have time to live a loathed slave,

Let him have time a beggar's orts to crave (981-85)

One may object that the poet in sonnet 66, "Tired with all these for restful death I cry," resorted again to a repetitive effect, but the repetition here is justified as a perfect reflection of his tiredness and annoyance.

Hoskyns accepted figures of repetition, but only those which were "freest from the oppinion of affectation." ${ }^{\prime 48}$ By 1598 we hear in Everard Gilpin's Skyalethia (Satyra Sexta) that even "wit's Caesar, Sidney" was "censur'd for affectation." Incidentally one may note 
that Sidney's inclination for pathetic fallacy still inspired several figures in the narrative poems, but apparently none in the Sonnets. ${ }^{49}$

Synoeceosis - the union of contraries - is a dominant figure in Venus and Adonis, epitomized in the line "Melodious discord, heavenly tune harsh sounding" (431).50 When Hoskyns wrote his Directions, this figure, earlier recommended by Puttenham, was, he said, "now in fashion," but "not like ever too bee so usuall," and he frowned upon it as "an easie figure" (150). Even more conspicuous in Shakespeare's narrative poems is a search for antithesis combined with symmetrical balance, as in Venus and Adonis:

Hunting he loved, but love he laughed to scorn. (4)

Ten kisses short as one, one long as twenty. (22)

And where she ends she does anew begin. (60)

But now I died, and death was lively joy. $(497-8)^{51}$

and in Lucrece:

Whose inward ill no outward harm expressed. (91)

That, cloyed with much, he pineth still for more. (98)

Full of foul hope and full of fond mistrust. $(284)^{52}$

Insistently repeated, these see-saw oppositions become tiresome. They seldom occur in the Sonnets, save in the couplets for the sake of an epigrammatic effect; ${ }^{53}$ reminiscent of the gnomic style widespread in the epyllia; but proverbs, when used, are more cleverly adapted $(94,95)$, and the close can become a striking metaphor $(33,98)$. Couplets often introduce a dramatic or ironic reversal $(2,3,12,15,30,34,40,66,69,73,84,91,92,129$, $130)$ or a paradox $(63,64,65)$. The deictics add a significant emphasis $(18,55,74)$ and the insistent play on intertwined personal pronouns, or on the word "love," conveys an intensity of personal feeling. ${ }^{54}$

Figures of purely emotional effect, however, tend to be discarded. In the Sonnets, as in the mature plays, the intensity of feeling is increasingly expressed in the simplest words. The density of Cordelia's "And so I am, I am" (Lear, IV.vii.69) is anticipated when the poet declares "I am that I am" (121) and finds it unnecessary to say more than "you alone are you" (84), or "And thou, all they, hast all the all of me" (31). When he tells his lover "thou art all my art" (78), he is not merely flattering. This adoption of a colloquial language becomes more and more noticeable in the sequence. ${ }^{55}$

23 If we turn from style to verse, another kind of "progress" is perceptible. In a sensitive study of "small differences" George Wright has shown that the metrical patterning in the sonnets "achieves a truly remarkable complexity and subtlety." ${ }^{56}$ Shakespeare resorts to rhetorical and prosodic figures "more intimate, more private, and more problematical" than in his early plays. These characteristics link the Sonnets with the speeches of Richard II and Hamlet, and "contrast sharply with the more declamatory self-appraisals of Tamburlaine or Richard III." ${ }^{57}$ The more "ruminative" sonnets, Wright elsewhere notes, are charged with an "inner verbal current" coming from a "personal consciousness." 58 They seem to convey the language of "silent thought," harbouring "unrevealed depths and contradictions," an illusion "secured by the metrical delicacy" which is "the chief gift of the Sonnets to the plays." 59

24 Another momentous change is the predominance of metaphor over simile in the Sonnets. André Breton considered the difference between metaphor and comparison as purely formal..$^{60}$ But a simile is based on a resemblance observable or demonstrable; it is analytic. A metaphor is synthetic. ${ }^{61}$ In these lines from Venus and Adonis a consistent comparison creates a picture: 
Look how a bird lies tangled in a net,

So fastened in her arms Adonis lies.

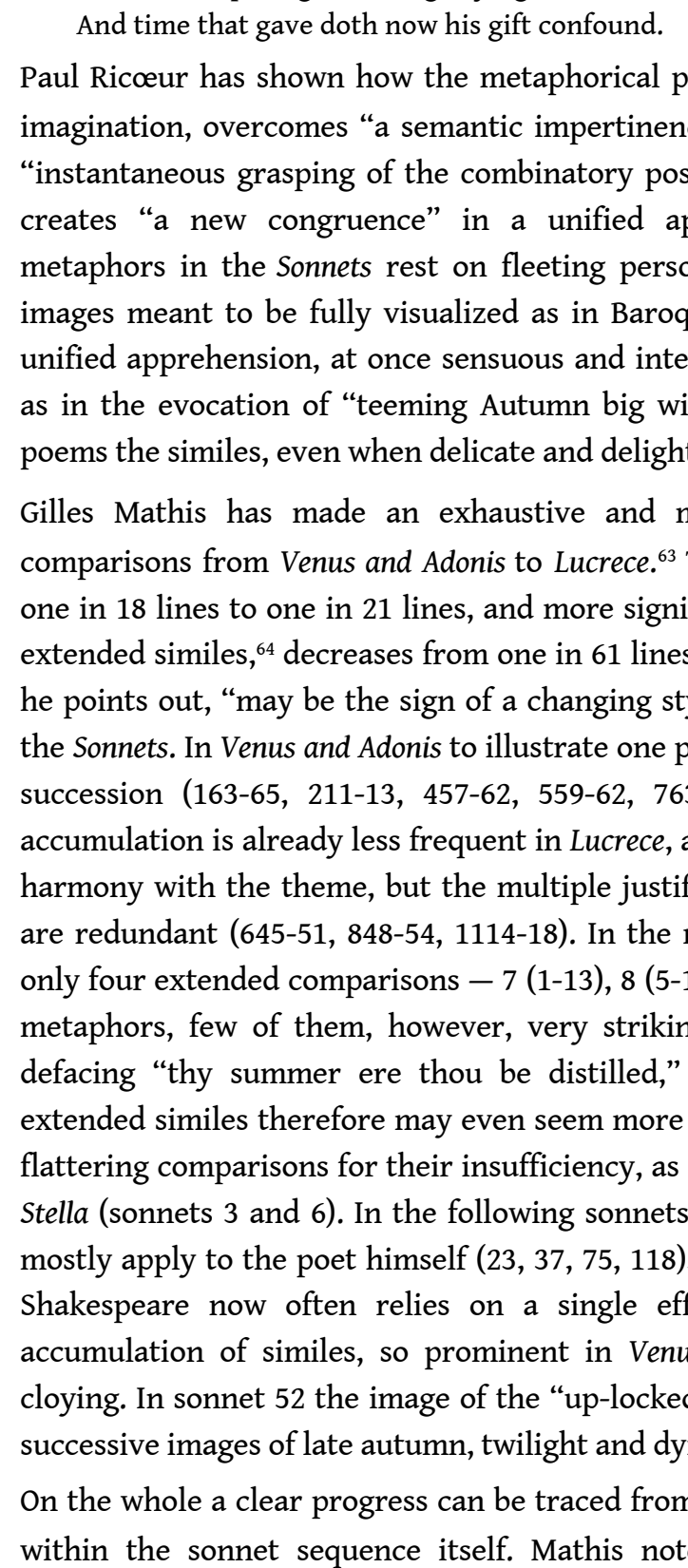
metaphors than Venus and Adonis. ${ }^{67}$ In the Sonnets a comparative scarcity of similes is offset by the multiplication of metaphors, and "mixed metaphors," characteristic of Shakespeare's mature dramatic style, become increasingly frequent. Statistics are unnecessary to appreciate the poet's growing disregard for apparent logic in his metaphors, though an inner imaginative logic is always at work as I have shown ${ }^{68}$ in sonnet 65:

Nativity, once in the main of light,

Crawls to maturity, wherewith being crowned,

Crooked eclipses 'gainst his glory fight,

In sonnet 60 , the initial comparison "Like as the waves..." is followed by a metaphorical evocation of the progress from infancy to old age which cannot be visualized and need not be logically justified: 
Since brass, nor stone, nor earth, nor boundless sea,

But sad mortality o'ersways their power,

How with this rage shall beauty hold a plea,

Whose action is no stronger than a flower?

O how shall summer's honey breath hold out

Against the wrackful siege of battering days

When rocks impregnable are not so stout,

Nor gates of steel so strong, but time decays?

o fearful meditation! where, alack,

Shall time's best jewel from time's chest lie hid,

Or what strong hand can hold his swift foot back,

Or who his spoil of beauty can forbid?

After the allusion to solid, durable substances, brass and stone, "earth," at once an element and the globe, together with the boundlessness of the sea, introduces a cosmic dimension. If all comes under the sway of mortality, what "action" - at once legal plea and strength - can beauty oppose to this rage in her weakness symbolized by a flower? This flower image calls up the thought of sweet scent, Summer's "honey breath;" but, by an abrupt leap of the imagination, the concept of "holding out" will evoke a besieged citadel battered by a destructive force. Hardly less surprising is the next succession of images when beauty becomes a jewel that Time will enclose in his chest, the grave, since no strong hand can hold his foot, arrest the flight of this thief. In baroque or emblematic poetry, like Crashaw's, the discordant images would be sharply visualized and seem grotesque. In Shakespeare's sonnet, the metaphors, as Frank Kermode observed in the plays written after 1599, "flash before us and disappear [...] before we can consider them:" ${ }^{69}$ we grasp the meaning and fail to notice what might seem incongruous.

Is this evolution a "progress"? I grant that poetry may resort to similes or metaphors with equal felicity: Shakespeare's metaphorical bent does not by itself give his language any pre-eminence over other great poets. But this preference for metaphor obviously accompanied (and probably resulted from) the growing maturity of his individual style and native genius. The Sonnets thus evidence a progress or change in three respects. The stereotyped rhetorical figures and the extended similes, so frequent in the narrative poems, disappear, or are sparsely and more subtly handled. Metaphorical language becomes predominant, with a growing use of mixed metaphors flouting consistency. Yet, within the sonnet sequence, the poet, like the dramatist, comes to rely on a plainer language for the expression of intense feeling.

Are there objective grounds for considering some poetic works superior to others? The difference between the "golden" style prevailing in the earlier sonnets as well as in Venus and Adonis, and the plain or bare style of later ones (I would not call it "drab") cannot be a criterion, for the preference is a matter of taste, and my catholicity of taste bids me abstain from choosing. I admit with Kant that taste is always subjective. Yet, instead of relying merely on a kind of universal consensus to justify the permanence of the greater works, I am inclined to claim that they fill special requirements.

From Aristotle to Aquinas, from Aquinas to James Joyce, and to the controversial aesthetics of Monroe Beardsley, ${ }^{70}$ the first criterion is unity. ${ }^{71}$ I would qualify it and require either unity or the kind of "controlled multiplicity" offered by some great works. Even so, I can hardly claim it for Shakespeare's Sonnets, though the poems to the young man approach it by "establishing the centre of all hopes, needs, desires, plans, pleasures and pain in the beloved," as Muriel Bradbrook rightly emphasized; and when Burrow 
speaks of the sequence as weaving together "a multiplicity of forms of order," this is close to my criterion of harmony in multiplicity. ${ }^{72}$

Beardsley's next criterion, "complexity," probably reflected a contemporary taste and smacks of subjectivity. I would substitute "wide range of interest." A great work of art may take a grain of sand as its object, but it must then invite us to see infinity in a grain of sand. There is a "world awareness" in the Sonnets which is not found in the narrative poems. In Venus and Adonis the cosmic significance of the myth is either absent, or so faintly alluded to, that it creates no imaginative expansion. In lines 451-56, we might be reminded of the hero's identification with the sun in some versions of the myth, but Venus addresses Adonis only as an "earthly sun" (198) and he himself complains "the sun doth burn [his] face" (186). The imagery and his metamorphosis rather link him with vegetation (the other version of the myth), but not with corn (as in Natalis Comes), and he will "wither" on the breast of Venus as a flower (1182). ${ }^{73}$ Venus had told Adonis that his death would bring about the end of the world, but it does not: she only indulged in a hyperbolic compliment. In the Rape of Lucrece the presence of a social background (at once past and present) is felt, but the major consequence of the action - the emergence of the Roman Republic - is obviously not the centre of interest. Despite the plea of Lucrece for moral virtue in the exercise of power and the final brief allusion to the overthrow of the Tarquins, the poem is mainly concerned with domestic values.

Several sonnets, though in a fragmentary way, show a greater social and historical awareness, ranging from "the old world" (59.9), its "pyramids" (123) and "gilded monuments" (55; cf. 64), through the "chronicle of wasted time" (106) to a "prophetic soul [...] dreaming on things to come" (107). ${ }^{74}$ Others associate the poet's feelings "with imagery of the sea, of growing things, with natural cycles of day, season, and year, and with many other ranges of reference." 75

Shakespeare's allusions to the "world" were frequent from the beginning of his career, ${ }^{76}$ but the term mainly alluded to the social world, or to "all men." It was seldom used (even in the Histories) for the whole extent of the earth (as it had been in Marlowe's Tamburlaine in association with power); seldom used also in its cosmic sense as in Dr. Faustus. ${ }^{77}$ World and sun are linked in Venus and Adonis since the sun is "the world's comforter" $(529,756,857)$, but mainly to mark phases of the day. The social meaning still prevails in the Sonnets $(1,3,9,19,71,72,75,81,90,129,138)$, yet an imaginative and symbolic enlargement is noteworthy in such lines as:

And do whate'er thou wilt, swift-footed time,

To the wide world... (sonnet 19)

Not mine own fears, but the prophetic soul

Of the wide world... (sonnet 107)

You are my all the world... (sonnet 112)

- and in the single use (in Shakespeare's writings ) of the term "universe":

For nothing this wide universe I call

Save thou, my rose. (sonnet 109) ${ }^{78}$

This expansion in space is paralleled by a heightened apprehension of time. In the narrative poems an artful management creates a sense of continuity and sets off the various episodes: attention is pinpointed on successive moments. ${ }^{79}$ Yet in neither poem is Time fully felt to be a power. The traditional association of the boar with winter in the Adonis myth of death and revival is unexploited. In The Rape of Lucrece a long apostrophe to Night and Opportunity (764-924) precedes the denunciation of "Time, copesmate of 
ugly night" (925), here taken to task for using Opportunity as his servant (932) instead of fulfilling his major "tasks of glory and of good" (to borrow Shelley's phrase in The Triumph of Life), or of general devastation: the fate of Lucrece was sealed by the opportunity Tarquin had of gaining access to her in the night.

In the Sonnets time is not only perceived in its historical depth $(59,107,123)$, but in all its implications, linking it with age and death (71-73). ${ }^{80}$ The present moment is related to the past (30), to "lovers gone" (31). As Augustine observed (Confessions, vil.xii), the soul distends itself to include past and future, to fortify itself "against that time" when love might cease $(49$, cf. 88$)$, or contemplate a future beyond death $(71,81)$, "not wond'ring at the present or the past" (123). A poet "all in war with Time" (15) confronts "this bloody tyrant" (16). When he considers how "wasteful time debateth with decay" (15), beholds Nativity crawling to maturity only to be confounded (60), and thinks "That time will come and take my love away" (64), the tragic emotion, absent from the catalogue of Time's contradictory actions in The Rape of Lucrece (939-59), arises from a sense of inevitability (the opposite of opportunity), conjoined with the instinctive refusal of man's consciousness to submit to necessity. In a previous essay I have argued that Shakespeare's intuition of time in the Sonnets combined a simultaneous attention to phenomena of growth and decay within the continual stream of time and a sense of irreversible continuity from the distant past to time's end. ${ }^{81}$

A growing preoccupation with the end of the world is, indeed, a distinctive trait in the Sonnets, as in some plays. Tarquin is incidentally described as an accessory to all sins, "From the creation to the general doom" (924). To flatter Adonis Venus says to him "the world hath ending with thy life" (12), but it won't. In the Sonnets the poet is more in earnest when he tells the young man that beauty's waste, "if all were minded so," in "threescore year would make the world away," and the later allusion to "the ending doom" (55; cf. 116) takes on its full value. ${ }^{82}$ We feel the presence of a Shakespearean anxiety, the anticipation that one day "all the breathers of this world" will be dead (81.12) and time will "come to his period," as later proclaimed in Antony and Cleopatra (Iv.xiv.107), This forethought will find its final expression, at once magnified and allayed, in Prospero's great speech (Tempest, iv.i.151-56).

In The Rape of Lucrece time was duly acknowledged to be "lackey to eternity" (967), but an intuition of a kind of this-worldy transcendence only appears in the Sonnets. Not in the eternity of fame the poet almost ironically promises to the anonymous paragon of mortal beauty, for he knows that his own supposedly "eternal lines" will only live "So long as men can breathe" (18) in "Time's thievish progress to eternity" (77); but through the intuition that Love "is not Time's fool" and possesses a transcendence of its own, which does not only ensure its constancy "to the edge of doom" (116), but can penetrate the very moment of present experience in "some special instant special blest" (52). The poet has gained an inner assurance that love "endureth all things" (1Cor. 13.7).

41 This world-awareness and this tragic time-awareness play, of course, an essential part in conferring intensity on the Sonnets, the intensity which "is the excellence of any art" according to Keats. ${ }^{83}$ "Intensity," Beardsley's third criterion for aesthetic evaluation, has been misinterpreted by Genette as violence or loudness. ${ }^{84}$ Keats's contemplation of the Grecian Urn and Wordsworth's meditation above Tintern Abbey are quietly intense. The etymological root is intendere: what is intense compels us to focus our attention. Poetic intensity makes the senses and the imagination, the mind, and at times the heart, ${ }^{85}$ intent on the aesthetic object. This is not achieved in all the sonnets. ${ }^{86}$ Many, however, as 
Stanley Wells and Paul Edmonson point out, "convey intensely personal, intensely vulnerable emotions" (p. 50), further enhanced by "the intensity of the sonnet form, the compact nature of the language" (p. 47). We are agreed on this essential point. I only wish to say once more that some sonnets give us a sense of triumphant permanence through the creation of form. ${ }^{87}$ I have to admit that this appeal to the criterion of intensity may introduce an element of subjectivity for the responses of different individuals may vary. With Antoine Compagnon one is free to choose a "well-tempered relativism" for the evaluation of a work of art, and yet maintain that value cannot be wholly "arbitrary." 88

\section{NOTES}

1. William Shakespeare, Tragicomédies II - Poésies (Paris: Robert Laffont, 2002). Henceforth cited as Ellrodt, Poésies.

2. Penguin, 2000, p. ix.

3. Poésies, 535-37, 620-22. See also Yves Peyré and François Laroque, William Shakespeare. Vénus et Adonis (Paris: Didier-Érudition, 1998), and Colin Burrow's Introduction in his edition of The Complete Sonnets \& Poems (Oxford: O.U.P., 2002).

4. The poem is considered "eminently stageworthy," yet the "fumbled gymnastics" can prove merely burlesque: see Philip C. Kolin, ed. Venus and Adonis. Critical Essays (New York: Garland, 1997), 54, 57.

5. Heather Dubrow admits Astrophil has a plot, but omits Spenser and Petrarch, in "The Politics of Plotting Shakespeare's Sonnets": James Schiffer (ed.), Shakespeare's Sonnets (New York: Garland, 2000). Though warning against a biographical interpretation, Burrow does not consider the sonnets as a "random sequence" (108ff.).

6. Stanley Wells (ed.), The Cambridge Companion to Shakespeare Studies (Cambridge: C.U.P., 1986), 36-38. Allusions to particular circumstances (besides the sonnets about the triangular relationship and the rival poet) are found in sonnets 35-36, 39, 57-58, 69-70, 87-89, 92-93, 109-112, $117,120-121,125(13), 152$. Iona Bell agrees that Shakespeare is writing "for a private audience which is already privy to the circumstances underlying the poem," which implies some relation to reality (Schiffer, 460, 463). Burrow (101-3) assumes that this web of allusions points to "coterie work," but coteries had a real existence.

7. Ellrodt, Poésies, 740.

8. Notably by Heather Dubrow, revising her own earlier position in Captive Victors (Schiffer, 113-24).

9. In the second group a few playful and graceful sonnets to a dark lady comparable to the Rosaline of Love's Labour's Lost are so different from the more passionate and cruder ones that I would be inclined to distinguish two addressees; but these poems could belong to an earlier period in the love relationship, before the revelation of the woman's profligacy.

10. Ellrodt, Poésies, 750-2. Paul Edmonson and Stanley Wells (30-31) note that the gender of the addressee is uncertain in a majority of sonnets, which is true, but cannot by itself disprove the pertinence of their distribution in the 1609 edition. A major break at sonnet 126 is accepted by Fineman, Engle and Thomas Green (as Joyce Sutphen points out), as well as by Margreta de Grazia: Schiffer, 202-3, 97. 
11. See the groups recorded in Poésies, 748-49, and Edmonson-Wells, 32-4, 61-2. Contrary to Dubrow's assertion (Schiffer, 123) the sequence does not "permit a reader to construct any number of narratives."

12. A common, yet uncertain interpretation: see my note, "The Limits of Interpretation in Shakespeare's Sonnets", Notes and Queries 249 (2004), 294.

13. A close parallel between these sonnets and lines 163-74 in Venus and Adonis creates a continuity. Yet there is a "progress" in appropriateness. When Venus attempts to seduce Adonis, she reminds him that his beauty should be preserved by generation, but she does not hold out to him the prospect of giving him a son herself; her argument is almost irrelevant in so far as her purpose is to secure immediate satisfaction for her desire. The young man of the Sonnets is urged to marry in order to ensure the continuance of his family as well as the preservation of his beauty; the aesthetic and social arguments dovetail.

14. S.10, "for love of me"; S.13, "dear my love"; S.15, "for love of you"; S.19, "my love".

15. See Notes and Queries 249 (2004), 295. Even if "nothing" is taken to be slang for the female genitals, the assumption that the thing added (the penis) can please the poet as the vagina of a woman pleases other men seems to be contradicted by the declaration that this addition "defeated" the poet.

16. An anxiety which proceeds from love, not sex, for one can always replace a sexual object.

17. Paul Edmonson and Stanley Wells (63) descry "a polyphony of attitudes and approaches to love" in the sonnets.

18. So is Cleopatra (with whom she is sometimes compared) in her first reaction to Antony's death (IV.xv.73), but Venus does not rise to the grandeur of Egypt's queen in her own death.

19. Even the "invisible" beauty of the voice (427-34) cannot be an aesthetic experience since Adonis had only grumbled a few words.

20. See Ellrodt, Poésies, 541.

21. Shakespeare and Elizabethan Poetry (Harmondsworth: Penguin, 1964), 63.

22. Catherine Belsey's assertion that the poem constructs "a promise of presence it fails to deliver" (Kolin, 262) hardly requires a Lacanian justification to be convincing. In "Narrative and the Forms of Desire in Shakespeare's Venus and Adonis" (Early Modern Literary Studies 52, September 1999, 1-24.) Gary Kuchar discerns a Lacanian "lack of being" in Venus's "failed attempt to have Adonis return her desire," an assertion based on lines 493-99 where a pun on "die" is supposed to express "a sense of total absence, loss, and lack;" but Venus here, after receiving a kiss, does "delight to die" in the usual erotic way.

23. Shakespeare. Les feux de l'amour (Paris: Grasset, 1990). Burrow (64) rightly calls attention to Tarquin's desire "to own a thing of costly worth."

24. Except in sonnets $127,128,131,132$, which might have been inspired by a different love affair, similar to Berowne's infatuation for a black-eyed wanton "that will do the deed" (Love's Labour's Lost, III.i.194-99).

25. Unregulated desire is sickness in sonnets 153 and 154, as Schoenfeldt points out (Schiffer, $310)$. The heart is spoken of as the seat of love $(141.3 ; 150.2)$, but it does not imply any tenderness for the heart as the seat of blood could be the fount of sexual desire.

26. This sex nausea may have led to Shakespeare's insistence on the purity and virginity of a heroine threatened by lust in a world of corruption, from Ophelia and Isabella to Marina and Miranda. I do not share the view that he was influenced by Puritanism in his last plays.

27. Sex, of course, is present in the "procreation sonnets," but it only concerns the young man, and he is only urged to marry in order to have children.

28. Edmonson-Wells, 68.

29. On Shakespeare's use of the word "love" in different circumstances, see Poésies, 747, footnote 2. Catherine Belsey has surveyed contemporary usage; see her "Love as trompe l'œil" in Kolin. 
30. The poet's allusion to his "sportive blood" in Sonnet 121 does not seem to be connected with his love for the young man, but with the "trespass" alluded to in the preceding sonnet, and we are not told how or with whom this trespass was committed. The pain of separation, often evoked, need not imply sexual desire.

31. Quoted in an Oxford Guide to Shakespeare, ed. Stanley Wells and Lena Cowen Orlin (Oxford: O.U.P., 2003), 441.

32. Del sentimiento tràgico della vida (1912); Le sentiment tragique de la vie (Paris: Gallimard, 1937), 150.

33. See "The Inversion of Cultural Traditions in Shakespeare's Sonnets" in Shakespeare and Cultural Traditions, T. Kishi, R. Pringle \& S. Wells eds. (Cranbury, NJ, and London: Associated University Presses, 1994), 91-96. Cited as Kishi.

34. See Cambridge Companion 1986, 39. My only dissent with Edmonson-Wells (70) concerns their emphasis on the sexual aspects of the poet's love in both the sonnets to the young man and the sonnets to the dark mistress when they describe them as "saturated with desire," quoting indiscriminately from both groups: e. g. sonnets 24,86 and 110 together with sonnets 128 and 141.

35. Gregory Wood, quoted in Edmonson-Wells, 71.

36. Marlowe, Hero and Leander, 61-70; Richard Barnfield, Poems 1594-1598 (The Affectionate Shepheard, I.22; Cynthia, Sonnet 17). The only allusion that might be overtly sensual in Shakespeare's sonnets to the young man is the "loving breast" of 110 , but it is qualified by "pure"; besides "breast" (instead of "heart") may have been called for by the rhyme here as in sonnet 48(11).

37. Ellrodt, Poésies, 753; Bate, The Genius of Shakespeare (London: Picador, 1997), 53.

38. On the difference between Shakespeare and Michelangelo see my article in Kishi, 94-5.

39. I have checked it in Spevack's Concordance.

40. See Mireille Ravassat, "Shakespeare, poésie et poétique dans les Sonnets", Bulletin de la société de stylistique anglaise 14 (1993), 14-24.

41. Shakespeare's Language, 13.

42. It has been claimed, that the composition of the first nineteen sonnets urging the young man to marry is an instance of copia. But each sonnet, while serving the same purpose, has a different theme and argument, which is different from the mere accumulation of images to prove one point in Venus and Adonis.

43. Shakespeare's Language, 29.

44. Shakespeare's Metrical Art (Berkeley: University of California Press, 1988), 78.

45. See Volume 3 of my Poètes Métaphysiques (Paris: Corti, 1960), chap. VIII.

46. The Life, Letters, and Writings of John Hoskyns, ed. Louise Brown Osborn (New Haven: Yale U.P., 1937).

47. In Lucrece see 414-16, 435-37, 569-72, 689-91, 849-52, 883-88, 890-94, 918-21, 940-44, 946-50, 953-58, 1023-26, 1199-1202. In Venus and Adonis 1123-27 and 1153-55 are typical examples.

48. Hoskyns, 128.

49. Venus and Adonis, 1-2, 665-66, 721-3, 982-84, 1032; Lucrece, 319-21, 1744-50.

50. Cf. "captive victor" in Lucrece, 730.

51. See also $93,94,111,389,804,837-838,912,962,966,995,1145-1158$.

52. See also 154, 200, 213-14, 222, 240, 247, 528, 610-611, 659-665, 688, 761, 867-872, 904-907, 974-980, 1032-1033. This kind of see-saw balance can be achieved without so neat an antithesis, e.g. in 743-746.

53. See sonnets $27,33,52,61,64,124,141,150$.

54. See sonnets $10,25,31,36,57,61,62,71,73,96,109,113$. The personal pronouns invite a spontaneous identification with the speaker.

55. Notably in sonnets $82-85,88-89,90-93$. I admit brief instances of colloquiality occur in the dialogue in Venus and Adonis (427-28) and in Lucrece (1270-95). 
56. Shakespeare's Metrical Art (Berkeley: University of California Press, 1988), 78-82. Wright's analyses set off a subtle rendering of emotional disturbance. The metre in sonnet 116 reflects "the problematical character of this absolute view of love" (84-7).

57. G.Wright, Shakespeare's Metrical Art, 88-9.

58. G. Wright in Schiffer, 148.

59. G. Wright, Shakespeare's Metrical Art, 89.

60. "Il ne saurait être fait grand état de la distinction purement formelle qui a pu être établie entre la métaphore et la comparaison. Il reste que l'une et l'autre constituent le véhicule interchangeable de la pensée analogique et que si la première offre la ressource de la fulgurance, la seconde [...] présente de considérables avantages de suspension;" Signe ascendant (Paris: Gallimard, 1949), 10.

61. Compare "Beauty's rose" in Sonnet 1 and Burns's "O my love's like a red, red rose / That's newly sprung in June."

62. "The Metaphorical Process as Cognition, Imagination, and Feeling" in On Metaphor, ed. Sheldon Sacks (Chicago and London: University of Chicago Press, 1978), 144-46. Ricœur, of course, acknowledges the "figurative character of metaphor," which often has a "pictorial dimension" (147). But it is a secondary characteristic, not fully present in all cases. He did not discuss the difference between metaphor and simile.

63. G. Mathis, "Homeric Similes in Venus and Adonis", in Venus et Adonis de William Shakespeare, ed. M. Abiteboul (Paris: Éditions du temps, 1998), 139-59, and "Shakespeare's Rape of Lucrece and Venus and Adonis in perspective: a stylistic analysis", in XVII-XVIII, Bulletin de la société d'études angloaméricaines des XVII et XVIII ${ }^{e}$ siècles 47 (1998), 25-54.

64. See particularly 55-59, 85-90, 289-294, 601-606, 817-828, 955-960 in Venus and Adonis; 505-511, 547-552, 708-716, 1009-1015, 1149-1155, 1226-1232, 1660-73 in Lucrece.

65. Mathis, art. cit., XVII-XVIII, 30.

66. Sonnets $1(2,5,11), 2(1-2,3-4), 3$ (5-6, 9-10), 4 (7-10, 14), 5 (9-10), 6 (1-2), 10 (7-8), 11 (13-4), 12 (7-8), 13 (9-11), $15(13-14), 16(2-3,6-7), 19$ (9-10). Some of these metaphors are fleeting personifications.

67. Mathis, art. cit., XVII-XVII, 42. In Lucrece the poet often relies on implicit comparisons, not introduced by "like" or "as," which brings them closer to metaphors, too often commonplace or aphoristic: e.g. 554-55, 577-81, 836-40, 1707-08.

68. Ellrodt, Poésies, 756. See also Helen Vendler's comment on Sonnet 60 in The Art of Shakespeare's Sonnets (Cambridge, Mass., and London: Harvard U.P., 1997). One may argue that mixed metaphors begin to appear in Venus, e.g. when Adonis opened his mouth and "the rubycoloured portal" "to his speech did honey passage yield / Like a red morn" (451-3). But "honey" is only a substitute for "sweet," "like" introduces a simile, and the "portal" of the morn is a conventional image.

69. Kermode, Shakespeare's Language, 16.

70. Aesthetics: Problems in the Philosophy of Criticism (Indianapolis, Hackett, 1981, $2^{\text {nd }}$ ed.), dismissed by Gérard Genette as “objectivist” in L'Euvre de l'art II, La relation esthétique (Paris: Seuil, 1997), 91-105.

71. For a discussion of "value" in art and in literary works see Genette, op. cit., and Antoine Compagnon, Le Démon de la théorie. Littérature et sens commun (Paris: Seuil, 1998), chap. 7.

72. Shakespeare and Elizabethan Poetry, 130 ; Burrow, 110.

73. Shakespeare seems to drop deliberately the larger implications of the myth in Spenser's Faerie Queene: see my Neoplatonism in the Poetry of Spenser (Geneva: Droz, 1960), 86-88.

74. The "obsessive concern with metaphorical wealth, profit, worth, value, expense" may also contribute to the sense of social density: Peter Herman in Schiffer, 263-83.

75. G. Wright, Shakespeare's Metrical Art (1988), 88. 
76. See Spevack's Concordance. There are 9 occurrences of the word in Venus and Adonis, 8 in Lucrece, but 33 in the Sonnets.

77. See A Concordance to the Works of Christopher Marlowe by Louis Uls (Hildesheim and New York, 1979).

78. See also thought's expansion to "the farthest earth" in Sonnet 44.

79. As I pointed out in Poésies, 535-36 and 620-21.

80. On the obsession with age see John Klause's article in Studies in Philology 80 (1993), 300-23.

81. See "La perception du temps dans les sonnets de Shakespeare" in Le Char ailé du Temps, ed. Louis Roux (Saint Étienne: Publications de l'Université de Saint Étienne, 2003), 39-42.

82. The word "doom" is predominantly used in the sense of judgment or sentence in Shakespeare's works. It does not occur in Venus and Adonis and out of four occurrences in Lucrece only one refers to the general doom. In the Sonnets however, apart from a sonnet to the mistress (145.7), the other occurrences either concern doomsday as the end of time $(55.12,116.12)$ or express finality $(14.14,107.4)$. The use of the word for the "general doom" is chiefly found in Hamlet (I.i.120, II.ii.238; v.i.59) and in Macbeth (IV.i.117; II.iii.78). This link between the Sonnets and the great tragedies is significant.

83. In his letter to George and Tom Keats, 22 Dec. 1817: Letters, ed. Buxton Forman (Oxford: O.U.P., 1960) 70. When adding that it must be "in close relationship with Beauty and Truth," Keats raises further questions; see John Keats, Poèmes, ed. R. Ellrodt (Paris: Imprimerie Nationale, 2000), 30-31.

84. L'Euvre de l'art, II, 100 .

85. I say "at times," for intensity and emotion are not necessarily linked. Yet, like Douglas Bush in Mythology and the Renaissance, I feel that Venus and Adonis suffers from a "fatal lack of emotion" in comparison with the best sonnets (quoted in Kolin, 96-7): inevitably, the presence of a narrator "distances events from their emotional investment" (Evans in Kolin, 10-11).

86. e.g. in the contorted sonnets on "hearts" and "eyes" $(24,46,47)$ and on the elements $(44,45)$.

87. As in Mrs Ramsay's reaction when finding "the essence sucked out of life and held rounded here" in Sonnet 98 (Virginia Woolf, To the Lighthouse, I, sect. 19). Despite the present trend the greater intensity in art and poetry still seems to me inseparable from an intuition of essence, or at least a willing suspension of disbelief in it.

88. Le Démon de la théorie, 302-4.

\section{ABSTRACTS}

A narrative and dramatic interest, dominant in the epyllia, is present in the Sonnets, though differently. The emphasis on sex, merely erotic in Venus and Adonis, related to a social ethic in the Rape of Lucrece, proves psychologically more complex in the sonnets to the Dark Lady. Desire is muted in the poems written by Shakespeare for the Young Man and this relationship evokes a richer variety of interests and emotions. In most sonnets the poet discards the stereotyped rhetorical figures profusely used in the narrative poems in favour of a metaphorical style in keeping with the evolution of his theatrical language. Despite their historical interest and occasional brilliance, the narrative poems are surpassed by the Sonnets which offer a wider view of world, time and mortality, with greater intensity and heightened poetic force. 
L'intérêt narratif et dramatique, dominant dans les epyllia, est présent dans les Sonnets, quoique de façon différente. La sexualité, purement érotique dans Vénus et Adonis, liée à une éthique sociale dans le Viol de Lucrèce, devient psychologiquement plus complexe dans les sonnets à la Dame brune. Mais le désir est mis en sourdine dans les poèmes écrits par Shakespeare pour le jeune homme et cette relation fait éclore une plus riche variété d'intérêts et d'émotions. Dans la plupart des sonnets le poète se détourne des figures de rhétorique stéréotypées répandues dans les poèmes narratifs en faveur d'un style métaphorique qui correspond à l'évolution de son langage théâtral. Malgré leur intérêt historique et leurs moments d'éclat, les poèmes narratifs sont surpassés par les Sonnets qui ouvrent des horizons plus vastes sur le monde, le temps et la mort, avec une plus grande intensité et une force poétique accrue.

\section{AUTHOR}

\section{ROBERT ELLRODT}

Robert Ellrodt est professeur émérite à l'Université Paris III - Sorbonne Nouvelle. Auteur notamment de Neoplatonism in the Poetry of Spenser (Droz, 1960), Les poètes métaphysiques anglais, 3 vols (Corti, 1960) et Seven Metaphysical Poets (Oxford U.P., 2000). Il a présenté Le Roi Lear dans le nouveau Shakespeare de la Pléiade (2002), traduit et présenté les poèmes et les sonnets dans le Shakespeare de la collection Bouquins (2002), ainsi que les poèmes de John Donne et de Keats (Imprimerie Nationale). 